\title{
Toxoplasma gondii: infection among shelter and stray cats in Rio de Janeiro, Brazil
}

\author{
Toxoplasma gondii: infecção entre os gatos de abrigo e de rua no Rio de Janeiro, Brasil \\ Pâmela Figueiredo Pereira ${ }^{1}$; Alynne da Silva Barbosa ${ }^{1,2}$; Ana Leticia Carvalho Santos ${ }^{1}$; Paula Forain Bolais ${ }^{3}$; \\ Marie-Laure Dardé3; Maria Regina Reis Amendoeira ${ }^{1 *}$
}

\author{
${ }^{1}$ Laboratório de Toxoplasmose e outras Protozooses, Instituto Oswaldo Cruz - IOC, Fundaçáo Oswaldo Cruz - FIOCRUZ, Rio de \\ Janeiro, RJ, Brasil \\ ${ }^{2}$ Laboratório de Parasitologia, Departamento de Microbiologia e Parasitologia, Instituto Biomédico, Universidade Federal Fluminense \\ - UFF, Niterói, RJ, Brasil \\ ${ }^{3}$ Institut d'Epidémiologie neurologique et de Neurologie Tropicale, Limoges, France
}

Received December 6, 2017

Accepted June 19, 2018

\begin{abstract}
The aim of this study was to identify possible infection of Toxoplasma gondii among cats in a shelter and a set of condominiums in the city of Rio de Janeiro, through changes to the cats' serological status between two different times in 2014 and 2015. One group was made up of captive cats at the municipal shelter and the other comprised stray cats that circulated in condominiums in the city. On the first occasion, cats were caught and tagged through application of microchips; in this manner, blood samples were obtained from 261 captive cats and 172 stray cats. On the second occasion, blood samples were obtained from 94 captive cats and 56 recaptured stray cats. The serological diagnosis was made by means of the indirect hemagglutination assay (IHA) and indirect immunofluorescence reaction (IFAT) (cutoff $\geq 64$ ). The frequency of T. gondii infection among the captive cats was $24.5 \%$ and among the stray cats, $18 \%$. With the second analysis, it was possible to verify modifications to the serological status of anti-T. gondii antibodies, in $18 \%$ of both populations of animals. The presence of seroconversion shows that infection was possibly occurring in the region at the time of the study.
\end{abstract}

Keywords: Toxoplasma gondii, captive cats, stray cats, immunodiagnosis, seroconversion.

\section{Resumo}

O objetivo deste estudo foi identificar uma possível infecção por Toxoplasma gondii entre gatos de abrigo e de um conjunto de condomínios na cidade do Rio de Janeiro, por meio de mudanças no status sorológico dos gatos em dois momentos diferentes em 2014 e 2015. O grupo foi formado por gatos, denominados cativos, de um abrigo municipal, e o outro por gatos de rua que circulavam em condomínios da cidade. Na primeira ocasiáo, os gatos foram capturados, microchipados e coletadas amostras de sangue de 261 gatos cativos e de 172 gatos de rua. Na segunda ocasião, as amostras de sangue foram obtidas de 94 gatos cativos e 56 de gatos de rua recapturados. O diagnóstico sorológico foi realizado por meio do ensaio de hemaglutinação indireta (HAI) e pela reação de imunofluorescência indireta (RIFI) (ponto de corte $\geq 64$ ). A frequência de infecção por T. gondii entre os gatos cativos foi de $24,5 \%$ e entre os gatos de rua $18 \%$. Com a segunda análise, foi possível verificar modificaçôes no status sorológico de anticorpos anti-T. gondii, em $18 \% \mathrm{em}$ ambas populaçôes de animais. A presença de soroconversão mostra que a infecção possivelmente ocorreu na região no momento do estudo.

Palavras-chave: Toxoplasma gondii, gatos cativos, gatos de rua, imunodiagnóstico, soroconversão.

\section{Introduction}

Toxoplasma gondii is an obligate intracellular zoonotic protozoon with worldwide distribution that can infect various cells in birds and mammals, including humans (JACOBS, 1974; TENTER et al.,

*Corresponding author: Maria Regina Reis Amendoeira. Laboratório de Toxoplasmose e outras Protozooses, Instituto Oswaldo Cruz IOC, Fundação Oswaldo Cruz - FIOCRUZ, Avenida Brasil, 4365, Manguinhos, CEP 21040-360, Rio de Janeiro, RJ, Brasil. e-mail: amendoeira.fiocruz@gmail.com; amendoei@ioc.fiocruz.br
2000). Felines, and especially domestic cats (Felis catus), are the most important animals in the life cycle of this parasite, since they are the only definitive hosts of the protozoon, and able to eliminate oocysts in their feces (DUBEY, 1995; AFONSO et al., 2006). These evolutionary forms are resistant to environmental conditions and, when sporulated, they can be ingested and infect intermediate hosts (mammals and birds). These hosts, including humans, may be infected through ingestion of tissue cysts in 
raw or undercooked meat or through congenital transmission (ROBERT-GANGNEUX \& DARDÉ, 2012).

Most of the time, these animals do not present clinical manifestations, but when these occur, the infection is usually multisystemic. The most common findings from feline toxoplasmosis are uveitis and fever, although enteritis, reactive lymph node hyperplasia, pneumonia and degenerative changes to the central nervous system have been reported (DUBEY \& LAPPIN, 2006; GALVÃO et al., 2014).

Toxoplasma gondii infection in cats can be shown directly through detection of oocysts in feces or indirectly through serological evaluation of anti-T. gondii antibodies (DUBEY \& BEATTIE, 1988; SAADATNIA \& GOLKAR, 2012). Serological analysis is the most widely used form of diagnosis in different groups of domestic cats. The prevalence rates of $T$. gondii vary greatly depending on the animal's lifestyle. In the case of cats living in their owner's home in different countries, the rates have ranged from $5.4 \%$ in Japan to $91.8 \%$ in Mexico (MARUYAMA et al., 2003; CASTILLO-MORALES et al., 2012), and from $4 \%$ in Rio de Janeiro, Brazil, to $45.2 \%$ in Colombia (NETTO et al., 2003; DUBEY et al., 2006). Among stray cats, i.e. free-living animals, the prevalence rates are still poorly reported, given that these cats generally acquire feral behavior and therefore become difficult to catch. In these studies, frequencies between $18 \%$ in France and $92.1 \%$ in Rio de Janeiro, Brazil have been reported (AFONSO et al., 2006; MENDES-DE-ALMEIDA et al., 2007).

Although many seroprevalence studies on T. gondii have been conducted on different animals, including cats, few have investigated the potential transmission of environmental infection. In this regard, only the studies by Afonso et al. (2006) in Lyon, France, and Mendes-de-Almeida et al. (2007) in Rio de Janeiro can be highlighted.

To investigate possible infection of this parasite among cats in different locations in Rio de Janeiro, the present study had the aim of determining the frequency of anti-T. gondii antibodies in two groups of cats: one consisting of captive cats in a shelter and the other consisting of stray cats, with emphasis on identification of their serological status from anti-T. gondii antibodies in blood collected from the same animals at two different times. The frequency of anti-T. gondii antibodies was also determined according to the sex of the animals.

\section{Materials and Methods}

\section{Ethical considerations}

This study received prior approval from the Animal Ethics Committee (CEUA) of FIOCRUZ, under license number LW 53/13 (P 24/13.7).

\section{Area and study population}

From August 2014 to October 2015, two distinct groups of cats living in different locations in the city of Rio de Janeiro were studied. The first group consisted of captive cats at a municipal shelter located in Guaratiba district, and the second group consisted of stray cats that circulated in a set of condominiums located in Barra da Tijuca district (Figure 1). Both districts are in the western zone of the municipality of Rio de Janeiro, although the captive cats at the municipal shelter came from several areas of the city, including some cats from a now-closed shelter that was located in the center of the city, which were already being studied by our research group (BOLAIS et al., 2017).

The municipal shelter provides various medical-veterinary services and animal support. It has an area of $13,000 \mathrm{~m}^{2}$, consisting of administrative areas, a clinical and surgical center and a management center for dogs, cats and horses. The shelter is responsible for receiving animals that are victims of abuse and neglect, which are made available for adoption soon after a period of quarantine.

The cat management center has animal accommodation facilities and an area for clinical support. It covers an area of $5,148 \mathrm{~m}^{2}$, and these grounds are covered with grass and some trees, with several enclosures for the animals containing "houses" constructed with masonry. In addition, there are some concrete yards that also function as enclosures and to enrich the environment. The entire space was delimited by high fences with aluminum sheeting in the upper portion to ensure that the animals would be unable to escape.

Most of the captive domestic cats in the municipal shelter were of domestic short-hair breeds. They had been rescued from the streets of the city of Rio de Janeiro or from irresponsible cat owners or had been abandoned on the spot. No histories were available for these cats, which made it difficult to obtain any information about them. They were receiving manufactured dry feed and potable water and were handled daily by the keepers. All of them received anti-rabies vaccine annually and anthelmintic drugs sporadically. Food was available through feeders and drinking water in shallow troughs in the enclosures, where the cats also slept. The shelter did not have litter boxes and therefore the cats used the environment of this cattery to defecate. Their feces were sporadically collected from the ground floor by the keepers.

The set of condominiums has an area of 780,000 $\mathrm{m}^{2}$, with an estimated population of 36,000 people with high purchasing power. This area was built within the Barra da Tijuca district, in a sustainable manner, in which the native fauna of the region was maintained. The area was delimited by restored sandspit and mangrove swamp vegetation and contained two parks (each with an area of $45,000 \mathrm{~m}^{2}$ ), five themed gardens and $3 \mathrm{~km}$ of flat urban ecological trails, alongside the unique mangroves preserved in an urban space of Rio de Janeiro.

In the set of condominiums, there are several environments that are arranged for the domestic stray cats that circulate in the region. These environments are known locally as "cat islands". It should be noted that the entire structure of the set of condominiums is managed by the residents' association, which is responsible for management of these islands. In all, ten islands were registered, consisting of plastic or wooden houses arranged on pallets, along with concrete and steel pipes to enrich the environment. The islands are strategically positioned in places with landscape structures that present natural elements and preserve the characteristics of the region. In these places, there are extensive areas of bare earth, grass and trees. 


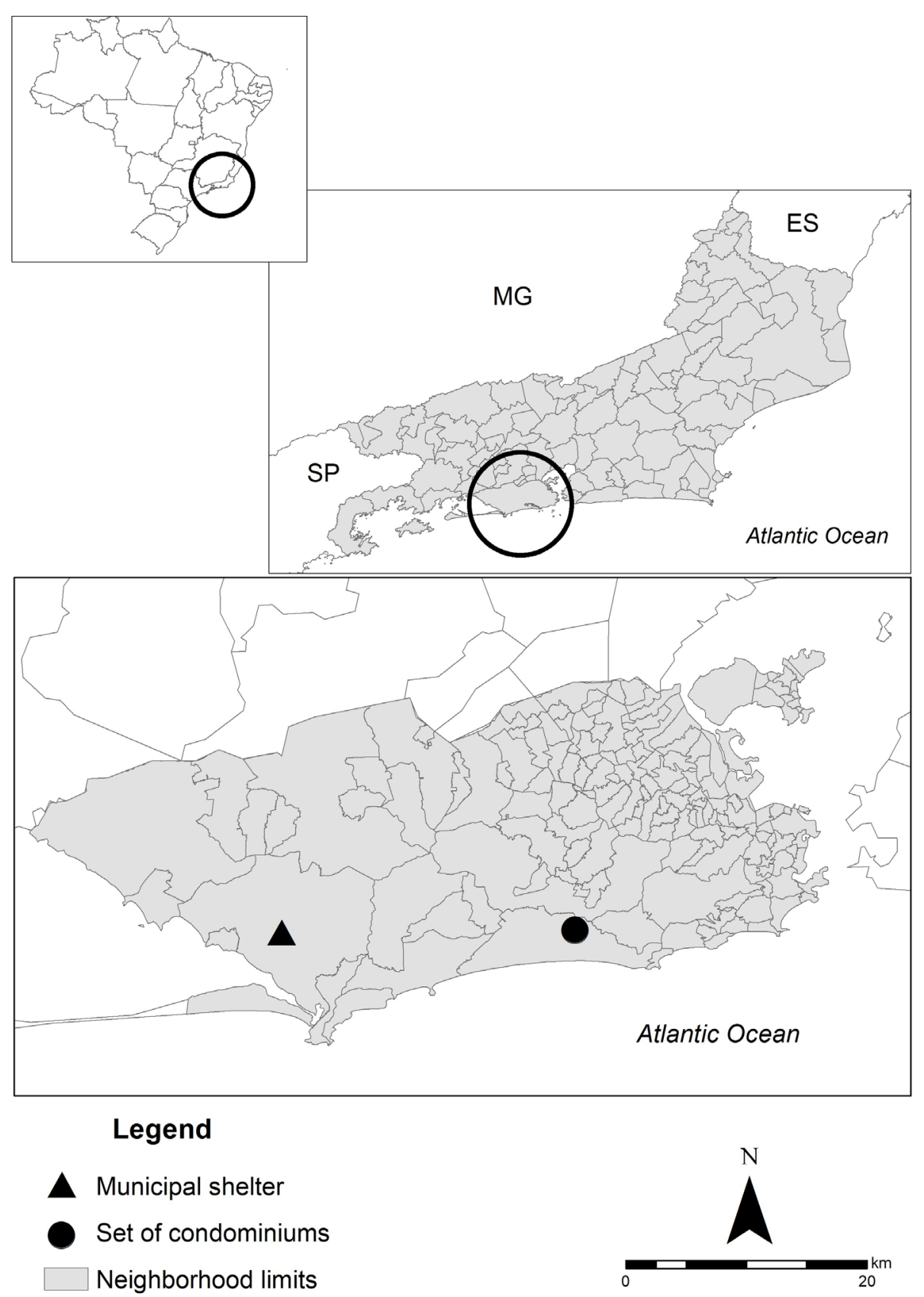

Figure 1. Locations of the municipal shelter and the set of condominiums within the city of Rio de Janeiro, highlighted on a map of the state of Rio de Janeiro, Brazil.

The stray cats that circulate through the set of condominiums were also mostly of domestic short-hair breeds and came to be present there through abandonment. They were routinely receiving manufactured dry food and drinking water, which were provided in drinking troughs and feeders on their islands by a handler hired by the residents' association. These cats were living freely in an environment of sandspits and natural vegetation, with little contact with humans, and many of them had ended up acquiring feral behavior. These cats in the condominium were not receiving any veterinary medical follow-up and had not been treated with intestinal anthelmintics or been vaccinated. During the study, the cats that were caught were sent for castration.

\section{Study design and sampling}

The animals participating in this study were subjected to blood sampling at two different times. On the first occasion, they were tagged through application of a microchip to identify each animal. The second sampling occurred after an interval of at least four months and at most eight months after the first collection. Identification of the animals on the second occasion was only possible through reading the microchip that had previously been applied.

The number of cats studied in the municipal shelter comprised the total number of animals present in the shelter. In the set 
of condominiums, it was decided to work using convenience sampling because of the difficulty of determining the total number of animals living there freely. Therefore, all the cats caught on the first occasion were included in this sample. In the second phase of the study, we tried to recapture only the cats that had participated in the first blood collection.

Capture, containment and identification of cats and sample collection

In order to make it easier to approach the cats in both the captive group and the stray group, moist manufactured food baits were used. After the captive cats had been attracted to the bait, they were then caught with the aid of a specific net. However, because the stray cats were free-living animals with feral behavior, their food baits were provided inside the "house-like" enclosure on their "cat island", which was already pre-adapted with traps. These traps had been built by hand by the cat handler himself. It was operated by hand, such that when the stray cats fed, the trapdoor was released, thus closing the exit of the house. These cats were then caught and placed in transportation boxes, and were sent to a specific place that had previously been prepared for handling the animals.

To tag the cats, they were subjected to a physical containment process using aluminum rods, towels and leather gloves. For this purpose, the Animal TAG $^{\circledR}$ sterile needle-type microchip was used, which has dimensions of $2 \mathrm{~mm}$ in diameter by $12 \mathrm{~mm}$ in length. This system was applied subcutaneously in the animal's dorsal region, between the scapulae and near the neck, by means of a syringe-shaped applicator. After this procedure, the dorsal region of the cat was again scanned using the Virbac BackHome $\mathrm{BioTec}^{\circledR} \mathrm{v} 500$ reader, to certify that the microchip had been applied correctly and was functioning. At the time of application of the microchips, the sex of the animals was recorded on technical sheets, along with their identification number, which was the same as that of the microchip. The ages of the animals were not analyzed because we did not know the origin of the animals and also because we did not have a specialist in the study team who could determine them.

A volume of $4 \mathrm{~mL}$ of peripheral blood was collected from each animal participating in the study. In most cats, blood collection was performed by means of puncturing the femoral or popliteal vein on the medial face of the limb using the disposable BD Vacutainer Safety-Lok ${ }^{\circledR}$ blood collection syringe, of dimensions $25 \mathrm{G}$ x 3/4" x 7" $(0.5 \mathrm{~mm} \times 19 \mathrm{~mm} \times 178 \mathrm{~mm})$. The blood was placed in collection tubes without anticoagulant $\left(\mathrm{BD}\right.$ Vacutainer serum $\left.{ }^{\circledR}\right)$. The samples were identified by means of a database serial number that was related to the animal's identification via the microchip. The samples were firstly kept at room temperature to allow formation and retraction of the clot and were then packed in reusable ice boxes and transported to the Laboratory for Toxoplasmosis and Other Protozoan Diseases of the Oswaldo Cruz Institute, Fiocruz. After all the procedures had been performed, the team returned the animals to the same place where they had been caught.

\section{Serological methods}

In the laboratory, the blood samples were centrifuged for 5 minutes at approximately $2000 \mathrm{~g}$, to separate the clot and obtain the serum. After this processing, aliquots of the biological material were transferred to $1.5 \mathrm{~mL}$ Eppendorf ${ }^{\circledR}$-type microtubes, which were identified. All the microtubes were stored in freezers at $-20^{\circ} \mathrm{C}$ until the serological tests were performed. The serum samples were processed to investigate anti-Toxoplasma gondii IgM and IgG antibodies using the indirect immunofluorescence test (IFAT), as described by Camargo (1974) and also to detect anti-Toxoplasma gondii IgG antibodies using the indirect hemagglutination assay (IHA) (Toxotest-HAI ${ }^{\circledR}$ kit, Wiener Laboratories). This technique was performed in accordance with the recommendations for the kit, including its cutoff point. Two dilutions (1:16 and 1:64) were used for IFAT IgM screening. In relation to $\mathrm{IgG}$, the following dilutions were used: $1: 16,1: 64,1: 256,1: 1024$ and 1:4096. The positive and negative controls used in this study were samples that had previously been determined, and these had been stored in freezers in the Laboratory for Toxoplasmosis and Other Protozoan Diseases. Anti-IgG and anti-IgM feline conjugates (Bio-Rad Laboratories Inc.) were used for the reaction. Reactions occurring at serum dilutions $\geq 1: 64$, in which complete fluorescence in the parasite membrane and in at least $50 \%$ of the tachyzoites was observed under the microscope, were considered positive. Dilutions less than 1:64 were considered negative or non-reactive (NR). The slides were read under a fluorescence epi-fluorescence (Nikon E400) Y-FL microscope, with a mercury light bulb and ND16 filter, with a magnification of $400 \mathrm{X}$.

Animals that were reactive to one or both serological techniques were considered positive for $T$. gondii, regardless of the sampling time at which the blood was collected. In the IFAT technique, positive animals were the ones that presented reactive serological results for one or both immunoglobulins (IgM or IgG).

\section{Statistical analysis}

Chi-square test was used to investigate associations of the frequencies of anti- $T$. gondii antibodies among the populations of captive and stray cats, frequencies of anti- $T$. gondii antibodies according to the animals' sex and frequencies of change of serological status regarding anti-T. gondii antibodies detected in the IFAT in the two groups of cats studied. Moreover, odds ratio was used to investigate the chance of one group of animals becoming infected with T. gondii when compared to another. In all analyses, a 5\% confidence interval was used. All statistical analyses were performed using the GraphPad Prism software, version 6.

\section{Results}

In the present study, it was observed that the sample size of the cat population differed between the two timepoints. At the first sample collection time, 261 captive cats and 172 stray cats were analyzed. The two groups of cats included in the study were firstly evaluated as correlations of the results obtained from the two collections from the same animal at different times with both techniques (IHA and IFAT). From this, anti-T. gondii antibodies were detected in $21.9 \%$ of the cats. However, when each group was analyzed separately, the positivity rates were $24.5 \%$ for the captive cats and $18.0 \%$ for the stray cats. There was no statistically significant difference between these results 
$(\mathrm{p}=0.1099)$. The chance (odds ratio - O.R.) for captive cats becoming infected with $T$. gondii when compared to stray cats was 1.478 (CI 95\% 0.9140 to 2.389) (Table 1).

The results from the two groups of cats studied were correlated independently of the collection time. This showed that the seropositivity rate for IgG antibodies using both techniques (IHA and IFAT) was $6.7 \%$ and the seronegativity rate was $78.5 \%$. The frequency of seropositivity for anti- $T$. gondii antibodies was investigated in relation to sex. No statistically significant difference was observed in either of the groups: captive cats $(p=0.2659)$ and stray cats $(\mathrm{p}=0.0647)$, associating the IHA and IFAT techniques. Among the captive cats, was $26.9 \%$ of the females and $20.8 \%$ of the males were serologically reactive. Among the stray cats, $13.6 \%$ of females and $24.6 \%$ of males were serologically reactive. The chance of the sex of the cat influencing the infection by the protozoan was 1.400 (O.R, CI 95\% 0.7727 to 2.537) for the captive cats and for the stray cats was 2.078 (O.R., CI 95\% 0.9471 to 4.561) (Table 2).

In the second phase of the study, we tried to recapture only the cats that had participated in the first blood collection. In this phase, new blood samples were obtained from 94 captive cats and 56 recaptured stray cats, and therefore only these cats participated in the two phases of the study. Among all the recaptured cats, it was observed that $27(18 \%)$ presented a change to their serological status regarding anti-T. gondii antibodies. Of these, 20/94 $(21.3 \%)$ belonged to the group of captive cats and $7 / 56(12.5 \%)$ to the group of stray cats. There was no statistically significant difference between the types of cats evaluated $(p=0.1760)$ and the chance of captive cats changed to their serological status was 1.892 (O.R., CI 95\% 0.7438 to 4.812) when compared with stray cats (Table 3).

When blood was collected from the same animal at two different times, patterns regarding changes to serological status could be inferred. Cats that were negative for $\operatorname{IgG}$ in the first analysis and positive for IgG in the second, or negative for IgM in the first and positive for IgM in the second, were considered to have undergone seroconversion (REY, 2006).
Cats that were positive for IgM in the first sample and negative for $\operatorname{IgM}$ in the second were not considered to have undergone seroconversion but to have undergone natural evolution of the serological status for this type of immunoglobulin, which tends become negative after approximately three weeks. Cats that were positive for $\mathrm{IgG}$ in the first sample and negative for IgG in the second were considered only to be animals whose serological status changed away from infection, because conventionally the term seroconversion refers to the time when antibodies for a given etiological agent become detectable.

Among the animals whose serological status changed according to the IFAT technique, three distinct types of serological status were observed: firstly, negative for IgG at the first collection and positive for IgG at the second collection, which was seen only among the captive cats; secondly, positive for $\operatorname{IgG}$ at the first collection and negative for $\operatorname{IgG}$ at the second collection, which was seen in all the stray cats and $10 \%$ of the captive cats; and thirdly, negative for IgM at the first collection and positive for $\operatorname{IgM}$ at the second collection, without change to IgG status, which was seen only among the captive cats (Table 4). All the animals that presented changes to serological status in the second analysis according to the IHA technique also presented changed to their status according to IFAT.

\section{Discussion}

Overall, the seroprevalence regarding anti-T. gondii antibodies observed among the total number of animals was $21.9 \%$. Although not statistically significant, the captive cats in the municipal shelter in Rio de Janeiro presented a serological frequency of anti- $T$. gondii antibodies that was greater than the group of stray cats in the set of condominiums, presenting, a greater chance of getting infected than the stray cats. This positivity can be directly related to the animals' way of life, in association with the specific biotic, abiotic and socioeconomic conditions of each site. Among the captive

Table 1. Frequency of anti-Toxoplasma gondii antibodies in captive and stray cats in Rio de Janeiro, regardless of the collection time.

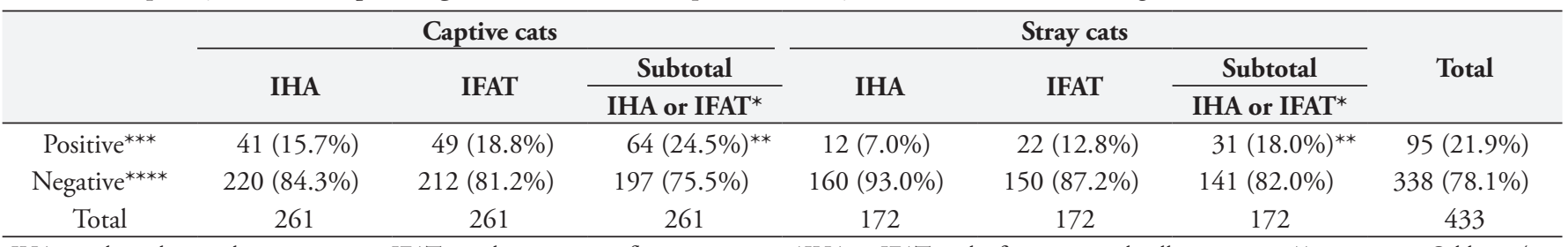

IHA $=$ indirect hemagglutination assay; IFAT $=$ indirect immunofluorescence test; ${ }^{*}$ IHA or IFAT at the first or second collection time; ${ }^{* *} \mathrm{p}=0.1099 ;$ Odd $=1.478$ (CI $95 \% 0.9140$ to 2.389 ). The value one (1) was covered. Odds ratio without statistical significance. ${ }^{* * *}$ only IgM-positive; IgM-positive and IgG-positive; only IgG-positive; ****negative for both immunoglobulins.

Table 2. Association between the serological results regarding anti-Toxoplasma gondii antibodies and the sex of the cats.

\begin{tabular}{ccccccccc}
\hline & \multicolumn{3}{c}{ Captive cats } & & & \multicolumn{3}{c}{ Stray cats } \\
\cline { 2 - 4 } & Female & Male & Total & & Female & Male & Total \\
\hline Positive & $43(26.9 \%)^{*}$ & $21(20.8 \%)^{*}$ & $64(24.5 \%)$ & & $14(13.6 \%)^{* *}$ & $17(24.6 \%)^{* *}$ & $31(18 \%)$ \\
Negative & $117(73.1 \%)$ & $80(79.2 \%)$ & $197(75.5 \%)$ & & $89(86.4 \%)$ & $52(75.4 \%)$ & $141(82 \%)$ \\
Total & 160 & 101 & 261 & & 103 & 69 & 172 \\
\hline
\end{tabular}

${ }^{*} \mathrm{p}=0.2659$ O.R. $=1.400$ (CI 95\% 0.7727 to 2.537$) ;{ }^{* *} \mathrm{p}=0.0647$; O.R. $=2.078$ (CI 95\% 0.9471 to 4.561). The value one (1) was covered. Odds ratio without statistical significance. 
Table 3. Comparison of the frequencies of change to serological status regarding anti-Toxoplasma gondii antibodies among the groups of captive and stray cats.

\begin{tabular}{cccc}
\hline $\begin{array}{c}\text { Change to } \\
\text { serological status }\end{array}$ & Captive cats & Stray cats & Total \\
\hline Yes & $20(21.3 \%)^{*}$ & $7(12.5 \%)^{*}$ & $27(18 \%)$ \\
No & $74(78.7 \%)$ & $49(87.5 \%)$ & $123(82 \%)$ \\
Total & 94 & 56 & 150 \\
\hline
\end{tabular}

${ }^{*} \mathrm{p}=0.1760$; Odd $=1.892$ (CI 95\% 0.7438 to 4.812). The value one (1) was covered. Odds ratio without statistical significance.

Table 4. Serological status regarding anti-Toxoplasma gondii antibodies according to the indirect immunofluorescence test (IFAT) in the groups of captive and stray cats.

\begin{tabular}{|c|c|c|c|}
\hline \multicolumn{2}{|c|}{ Serological status } & \multirow[b]{2}{*}{$\begin{array}{l}\text { Captive cats } \\
\qquad(\mathrm{n}=94)\end{array}$} & \multirow[b]{2}{*}{$\begin{array}{c}\text { Stray cats } \\
(\mathrm{n}=56)\end{array}$} \\
\hline $\begin{array}{c}\text { 1st collection } \\
\text { time }\end{array}$ & $\begin{array}{c}\text { 2nd collection } \\
\text { time }\end{array}$ & & \\
\hline IgG - & $\operatorname{IgG}+$ & $16(80 \%)$ & 0 \\
\hline $\operatorname{IgG}+$ & $\operatorname{IgG~-~}$ & $2(10 \%)$ & $7(100 \%)$ \\
\hline $\operatorname{Ig} M-$ & $\operatorname{Ig} M+$ & $2(10 \%)$ & 0 \\
\hline \multicolumn{2}{|c|}{ Total } & 20 & 7 \\
\hline
\end{tabular}

(-) serologically negative; (+) serologically positive.

cats in the shelter, the frequency was $24.5 \%$. Similar results were observed among cats at zoonosis control centers (ZCC) in Rio de Janeiro and São Paulo, Brazil: 24.4\% and 25\%, respectively (NETTO et al., 2003; BRESCIANI et al., 2007). Higher frequencies were reported among captive cats at a ZCC in São Paulo (35\%) by Pena et al. (2006) and among cats in a public shelter in Colombia (45.2\%) by Dubey et al. (2006). The population density of cats may have been one of the factors that favored $T$. gondii infection in the municipal shelter. In the present study, it was found that this variable was higher in the shelter $\left(0.07\right.$ animals $\left./ \mathrm{m}^{2}\right)$ than in the set of condominiums $\left(0.0002\right.$ animals $\left./ \mathrm{m}^{2}\right)$. The high concentration of animals in the shelter may have favored direct contact with feces and bare soil that was possibly contaminated with oocysts that, when sporulated, infect other animals that are on the site.

Among the stray cats of the set of condominiums, the seropositivity for $T$. gondii was $18 \%$. This percentage was also reported by Afonso et al. (2006), in France, in detecting antibodies to these protozoa among free-living cats in a park in Lyon. Results higher than those of the present study were detected among stray cats in military bases in Iraq (30.4\%) and among cats in urban centers in Iran (44.2\%) (AKHTARDANESH et al., 2010; KASTEN et al., 2013). In Brazil, high frequencies in populations of stray cats were shown by Costa et al. (2012) in Fernando de Noronha, 66.6\%, and by Mendes-de-Almeida et al. (2007) in Rio de Janeiro, with serological results ranging from $60.6 \%$ to $92.1 \%$.

The lower frequency observed in the group of stray cats in the present study, in comparison with the captive cats at the shelter and with reports in the literature, may have occurred due to factors limiting the exposure of cats to different sources of infection in the environment. Although the stray cats in the set of condominiums were free-living animals, they circulated in an environment where human interference was present. They received nutritional support through daily supply of manufactured food and drinking water and also received sanitary management, albeit limited, through cleaning of their enclosures. Nevertheless, because they were free-living animals, a certain percentage of them would be expected to be serologically positive for anti-T. gondii antibodies, and this was indeed observed among the stray cats studied. This suggests that the broad natural environment of the set of condominiums, consisting of restored sandspit and mangrove vegetation, favored maintenance of the biological cycle of these protozoa. Thus, these free-living cats were able to use their hunting instincts, which allowed then to become infected through ingestion of intermediate hosts infected with tissue cysts.

In the present study in the captive cats, females presented a higher odds ratio for infection than males and among the stray cats, males had a higher chance of becoming infected than females. However, there wasn't observed difference statically significance in the frequency of $T$. gondii infection in relation to the sex of the cats in the two populations included in this study. This was concordant with results reported in Spain, Peru, São Paulo and Rio de Janeiro, Brazil (GAUSS et al., 2003; PENA et al., 2006; BRESCIANI et al., 2007; COELHO et al., 2011; CERRO et al., 2014; BARROS et al., 2015). According to Smith et al. (1992) and Miró et al. (2004), male cats may present a higher risk of $T$. gondii infection than females because of their greater territorial exploitation of the environment. On the other hand, Netto et al. (2003) pointed out that females and their offspring might have greater possibility of infection because of maternal hunting behavior aimed towards stimulating this habit in their offspring. It is important to note that most of the shelter cats had been neutered, while the stray cats were whole, since during the period of study in the condominium a castration project was only just being started. It should be emphasized that castrated cats will explore their environment to a lesser extent, and thus that sterilization would act as a control measure, since it could minimize the exposure to infection by the protozoon.

The evaluation on possible infection of $T$. gondii was performed on $36.01 \%$ of the captive cats and $32.5 \%$ of the stray cats. This was because at the second sample collection time it was not possible to find some of the animals that had previously been sampled. The absence of these individuals, second phase of the study, from the municipal shelter may have been due to escapes, deaths or adoptions. Among the stray cats in the set of condominiums, the decrease in population size between the first and second capture times can be explained by deaths, adoptions and the ability of the animals to recognize the handlers and the traps used (which can be associated with the cats' feral behavior), which in many cases made it difficult to recapture them. Furthermore, because the stray cats probably roamed widely, they may not have been present in the set of condominiums at the time of the second sample collection.

During the study, it was seen that the serological status of $18.0 \%$ of the animals changed. Despite living in very different environments, the captive and stray cat groups did not present any statistically significant differences regarding changes to serological status, which showed that both groups were in environments that somehow favored infection by these protozoa. Although the change in serological status was more detected in captive cats, group of 
animals that presented a greater chance of becoming infected and, consequently, a greater chance of altering their serological status. In France, Afonso et al. (2006) followed up stray cats serologically and detected a lower rate of change to serological status (9.1\%) than what was identified in the cats of the present study in Rio de Janeiro. Those authors considered that seroconversion had occurred when kittens ( $<6$ months) presented titers higher than the cutoff point (1:40) or when adult cats ( $>6$ months) presented titers $\geq 1: 40$ after a certain period (second blood collection). It is noteworthy that the samples from the cats evaluated in Rio de Janeiro were subjected to the IFAT technique with a cutoff point of 64. In addition, IFAT made it possible to distinguish the class of immunoglobulins and thus to estimate the phase of the infection. This was not possible in the study in France, because those samples were evaluated only using the MAT technique.

In the present study, among the animals that showed changes to serological status, the most evident seroconversion among the captive cats was from negative for IgG in the first laboratory analysis to positive for IgG in the second. Also among these animals, a change to serological status from negative for IgM to positive for IgM was observed. These status changes indicate that the animals probably came into contact with the parasites' evolutionary forms in the environment of the municipal shelter, and that they had already undergone multiplication at the intestinal level, thus giving rise to infection. It is known that production of anti- $T$. gondii antibodies in felids, which are the only definitive hosts of this parasite, occurs after maximum elimination of oocysts in the intestinal contents, which usually occurs three weeks after infection, when the signs and symptoms of toxoplasmosis are no longer so evident in these animals (DUBEY, 1995). This infection in the shelter environment may have occurred due to several factors: environmental contamination with feces containing oocysts; high concentration of animals, which would favor direct contact between them and their excreta; and ingestion of contaminated water from shallow containers arranged on the ground, in contact with the soil. In addition, the possibility of ingesting cysts with bradyzoites, from intermediate hosts that might enter the enclosure, such as rodents, marsupials and birds, cannot be ruled out, because the municipal shelter studied is located in an environment close to the Atlantic Forest.

All seven stray cats that showed serological changes were positive for IgG at the first blood collection and negative for IgG at the second. This modification in anti- $T$. gondii antibody status was also observed in three cats among a group of strays studied by Mendes-de-Almeida et al. (2007) in Rio de Janeiro from 2002 to 2004 . This category can be explained by the presence of antibodies at basal levels at the second analysis time that were not detected through the cutoff point adopted. It should be noted that out of the seven stray cats that became IgG-negative, four animals had titers of 1:16 for anti-T. gondii antibodies at the second timepoint and three animals were not reactive at any of the dilutions used. It is known that for felines there are still no standard cutoff points for the serological techniques that are used for diagnosing anti-T. gondii antibodies (LANGONI et al., 2001; BRESCIANI et al., 2007). Therefore, the cutoff ends up being a choice of each researcher. As the objective of this study was to evaluate the change in serological status, choose a higher cutoff point to be sure that it was changed of the serological status.

In indirectly evaluating $T$. gondii infection in captive and stray cats, the percentage positivity obtained was found to be like what had been observed at other locations. However, the present study not only evaluated spot seroprevalence, but also, whenever possible, emphasized sample collection at two distinct times for each cat. This enabled identification of animals whose serological status changed to positive for anti-T. gondii antibodies, which demonstrated the possible presence of sources of infection for these, highlighting the captive cats, because in those cats it was clearly detected the seroconversion.

\section{Acknowledgements}

We would like to thank the Department of Animal Welfare and Protection of the municipality of Rio de Janeiro and the ASSAPE association. We are grateful to Mauro Lúcio de Andrade and all those who participated in the sampling.

\section{References}

Afonso E, Thulliez P, Gilot-Fromont E. Transmission of Toxoplasma gondii in an urban population of domestic cats (Felis catus). Int J Parasitol 2006; 36(13): 1373-1382. http://dx.doi.org/10.1016/j.ijpara.2006.07.010. PMid:16989836.

Akhtardanesh B, Ziaali N, Sharifi H, Rezaei S. Feline immunodeficiency virus, feline leukemia virus and Toxoplasma gondii in stray and household cats in Kerman-Iran: seroprevalence and correlation with clinical and laboratory findings. Res Vet Sci 2010; 89(2): 306-310. http://dx.doi. org/10.1016/j.rvsc.2010.03.015. PMid:20362315.

Barros RS, Menezes RC, Pereira SA, Figueiredo FB, Oliveira RVC, Nicolau JL, et al. Feline sporotrichosis: coinfection with Toxoplasma gondii, feline immunodeficiency virus and feline leukemia virus in cats from an endemic area in Brasil. Acta Sci Vet 2015; 43: 1316.

Bolais PF, Vignoles P, Pereira PF, Keim R, Aroussi A, Ismail K, et al. Toxoplasma gondii survey in cats from two environments of the city of Rio de Janeiro, Brazil by modified agglutination test on sera and filter-paper. Parasit Vectors 2017; 10(1): 88. http://dx.doi.org/10.1186/s13071-0172017-8. PMid:28212681.

Bresciani KDS, Gennari SM, Serrano ACM, Rodrigues AAR, Ueno T, Franco LG, et al. Antibodies to Neospora caninum and Toxoplasma gondii in domestic cats from Brazil. Parasitol Res 2007; 100(2): 281-285. http:// dx.doi.org/10.1007/s00436-006-0262-4. PMid:16941188.

Camargo ME. Introdução às técnicas de imunofluorescência. Rev Bras Patol Clin 1974; 10(30): 143-169.

Castillo-Morales VJ, Acosta Viana KY, Guzmán-Marín ES, Jiménez-Coello M, Segura-Correa JC, Aguilar-Caballero AJ, et al. Prevalence and risk factors of Toxoplasma gondii infection in domestic cats from the tropics of Mexico using serological and molecular tests. Interdiscip Perspect Infect Dis 2012; 2012: 529108. http://dx.doi.org/10.1155/2012/529108. PMid:22997512.

Cerro L, Rubio A, Pinedo R, Mendes-de-Almeida F, Brener B, Labarthe N. Seroprevalence of Toxoplasma gondii in cats (Felis catus, Linnaeus 1758) living in Lima, Peru. Rev Bras Parasitol Vet 2014; 23(1): 90-93. http:// dx.doi.org/10.1590/S1984-29612014013. PMid:24728367. 
Coelho WMD, Amarante AFT, Apolinário JC, Coelho NMD, Lima VMF, Perri SHV, et al. Seroepidemiology of Toxoplasma gondii, Neospora caninum, and Leishmania spp. infections and risk factors for cats from Brazil. Parasitol Res 2011; 109(4): 1009-1013. http://dx.doi.org/10.1007/ s00436-011-2461-x. PMid:21626423.

Costa DG, Marvulo MFV, Silva JSA, Santana SC, Magalhães FJR, Lima CDF Fo, et al. Seroprevalence of Toxoplasma gondii in domestic and wild animals from the Fernando de Noronha, Brazil. J Parasitol 2012; 98(3): 679-680. http://dx.doi.org/10.1645/GE-2910.1. PMid:22150091.

Dubey JP, Beattie CP. Toxoplasmosis of animals and man. Boca Raton: CRC Press; 1988.

Dubey JP, Lappin MR. Toxoplasmosis and neosporosis. In: Greene CE, editor. Infectious diseases of the dog and cat. 3rd ed. St Louis: Elsevier; 2006. 754 p.

Dubey JP, Su C, Cortés JA, Sundar N, Gomez-Marin JE, Polo LJ, et al. Prevalence of Toxoplasma gondii in cats from Colombia, South America and genetic characterization of T. gondii isolates. Vet Parasitol 2006; 141(1-2): 42-47. http://dx.doi.org/10.1016/j.vetpar.2006.04.037. PMid:16797845.

Dubey JP. Duration of immunity to shedding of Toxoplasma gondii oocysts by cats. J Parasitol 1995; 81(3): 410-415. http://dx.doi. org/10.2307/3283823. PMid:7776126.

Galvão ALB, Vaconcellos AL, Navarro IT, Bresciani KDS. Aspectos da toxoplasmose na clínica de pequenos animais. Semina: Ciênc Agrár 2014; 35(1): 393-410. http://dx.doi.org/10.5433/1679-0359.2014v35n1p393.

Gauss CBL, Almería S, Ortuño A, Garcia F, Dubey JP. Seroprevalence of Toxoplasma gondii antibodies in domestic cats from Barcelona, Spain. J Parasitol 2003; 89(5): 1067-1068. http://dx.doi.org/10.1645/GE-114. PMid:14627161.

Jacobs L. Toxoplasma gondii: parasitology and transmission. Bull N $Y$ Acad Med 1974; 50(2): 128-145. PMid:4592094.

Kasten RW, Kass PH, McMillan-Cole AC, Stuckey MJ, Chomel BB, Switzer AD. Bartonella and Toxoplasma Infections in Stray Cats from Iraq. Am J Trop Med Hyg 2013; 89(6): 1219-1224. http://dx.doi.org/10.4269/ ajtmh.13-0353. PMid:24062480.

Langoni H, Silva AV, Cabral KG, Cunha ELP, Cutolo AA. Prevalência de toxoplasmose em gatos dos Estados de Sáo Paulo e Paraná. BrazJ Vet Res Anim Sci 2001; 38(5): 243-244. http://dx.doi.org/10.1590/S141395962001000500009.
Maruyama S, Kabeya H, Nakao R, Tanaka S, Sakai T, Xuan X, et al. Seroprevalence of Bartonella henselae, Toxoplasma gondii, FIV and FeLV infections in domestic cats in Japan. Microbiol Immunol 2003; 47(2): 147-153. http://dx.doi.org/10.1111/j.1348-0421.2003.tb02798.x. PMid:12680718.

Mendes-de-Almeida F, Labarthe N, Guerrero J, Faria MCF, Branco AS, Pereira CD, et al. Follow-up of the health conditions of an urban colony of free-roaming cats (Felis catus Linnaeus, 1758) in the city of Rio de Janeiro, Brazil. Vet Parasitol 2007; 147(1-2): 9-15. http://dx.doi. org/10.1016/j.vetpar.2007.03.035. PMid:17481822.

Miró G, Montoya A, Jiménez S, Frisuelos C, Mateo M, Fuentes I. Prevalence of antibodies to Toxoplasma gondii and intestinal parasites in stray, farm and household cats in Spain. Vet Parasitol 2004; 126(3): 249 255. http://dx.doi.org/10.1016/j.vetpar.2004.08.015. PMid:15567588.

Netto EG, Munhoz AD, Albuquerque GR, Lopes CWG, Ferreira AMR. Ocorrência de gatos soropositivos para Toxoplasma gondii Nicolle e Manceaux, 1909 (Apicomplexa: Toxoplasmatinae) na cidade de Niterói, Rio De Janeiro. Rev Bras Parasitol Vet 2003; 12(4): 145-149.

Pena HFJ, Soares RM, Amaku M, Dubey JP, Gennari SM. Toxoplasma gondii infection in cats from Sáo Paulo state, Brazil: seroprevalence, oocyst shedding, isolation in mice, and biologic and molecular characterization. Res Vet Sci 2006; 81(1): 58-67. http://dx.doi.org/10.1016/j.rvsc.2005.09.007. PMid:16289158.

Rey L. Dicionário de saúde e da prevençâo de seus riscos. Rio de Janeiro: Guanabara Koogan; 2006.

Robert-Gangneux F, Dardé ML. Epidemiology of and diagnostic strategies for toxoplasmosis. Clin Microbiol Rev 2012; 25(2): 264-296. http:// dx.doi.org/10.1128/CMR.05013-11. PMid:22491772.

Saadatnia G, Golkar M. A review on human toxoplasmosis. Scand J Infect Dis 2012; 44(11): 805-814. http://dx.doi.org/10.3109/00365548.2012 .693197. PMid:22831461.

Smith KE, Zimmerman JJ, Patton S, Beran GW, Hill HT. The epidemiology of toxoplasmosis on Iowa swine farms with an emphasis on the roles of free-living mammals. Vet Parasitol 1992; 42(3-4): 199-211. http://dx.doi. org/10.1016/0304-4017(92)90062-E. PMid:1496780.

Tenter AM, Heckeroth AR, Weiss LM. Toxoplasma gondii: from animals to humans. Int J Parasitol 2000; 30(12-13): 1217-1258. http://dx.doi. org/10.1016/S0020-7519(00)00124-7. PMid:11113252. 